\title{
Application of LCC software for karwadi watershed
}

\section{A.M. KAMBLE, N.M. TAMBOLI, A.L. PATHAN AND K.S. SHINDE}

Received : $30.07 .2015 ;$ Revised : 07.03.2016; Accepted : 20.03.2016

See end of the Paper for authors' affiliation

Correspondence to :

\section{A.M. KAMBLE}

Department of Agricultural Engineering, College of Agriculture, Vasantrao Naik Marathwada Krishi Vidyapeeth, PARBHANI (M.S.) INDIA

Email : anish_kamble@

rediffmail.com
-ABSTRACT : The basic principle of soil and water conservation is to use the land according to its capability. Therefore, the knowledge of land capability classification is a prerequisite and important for planning of watershed development programme. The capability of land depends upon the characteristics of the land like slope, erosion status, soil depth and soil type. Considering these input parameters land capability classification (LCC) software is developed in ' $\mathrm{C}$ ' programming language. This software can be executed on different platforms like windows, linux etc. mostly without any modification. The developed LCC software is executed successfully with the different conditions. Further the software is tested for Karwadi watershed (survey number 133 and 154) near Nandapur, Tq. Kalamnuri, Dist. Hingoli (M.S.) with different conditions. Field results shown by this LCC software are compared with the results obtained theoretically by considering ranges given in the standard table and were found similar. After successful testing it is concluded that the software is useful for suggesting the soil and water conservation practices for watershed development plan.

- KEY WORDS : Land capability classification, Software, Watershed, Land

- HOW TO CITE THIS PAPER : Kamble, A.M., Tamboli, N.M., Pathan, A.L. and Shinde, K.S. (2016). Application of LCC software for karwadi watershed. Internat. J. Agric. Engg., 9(1) : 78-85. 